\section{Bell Pepper Plant Development over Mulches of Diverse Colors}

\author{
Dennis R. Decoteau \\ Department of Horticulture, Clemson University, Clemson, \\ SC 29634-0375
}

\section{Michael J. Kasperbauer and Patrick G. Hunt \\ U.S. Department of Agriculture, Agricultural Research Service, Coastal \\ Plains Soil and Water Conservation Research Center, Florence, \\ SC 29502-3039}

\begin{abstract}
Additional index words. Capsicum annuum, mulch color, reflected light, phytochrome, plant morphology
\end{abstract}

Abstract. Mulch surface color affected the growth of bell pepper (Capsicum annuum L.) plants, the amount and quality of upwardly reflected light, and the soil temperatures under the mulch. Of the surface colors evaluated (black, red, yellow, and white), plants grown over red mulch were the tallest. The darker (black and red) mulches reflected less total light and more far-red (FR) relative-to-red (R) light, and soil temperatures recorded in the afternoon and evening were warmer than under the yellow and white mulches. Plant growth responses to mulch surface color were also observed when soil temperature differences among the mulch color treatments were minimized by placing insulation boards between the mulch surface and the soil. Sensitivity of young pepper plants to a high or low FR: R light ratio was demonstrated by exposing plants to 15 minutes of FR or 15 minutes of $\mathrm{R}$ light at the end of the photosynthetic period each day for 14 consecutive days in a controlled environment. Plants that received the FR (high FR : R ratio) were $51 \%$ taller than plants exposed to R (low FR : $\mathrm{R}$ ratio) light treatments. The similar responses of pepper plants to differences in FR : $\mathrm{R}$ ratios associated with mulch color and end-of-day light treatments provide evidence that pepper plant growth is affected by relatively small changes in light environment induced by the surface color of the mulch.

Increased yields of bell peppers have been reported when plastic (polyethylene) mulch, often in combination with soil fumigation and trickle irrigation, was used in field production (Brown et al., 1986; Kovalchuk, 1983; Monette and Stewart, 1987). Use of plastic mulch increases production costs, but net economic returns are also greater (Brown et al., 1986; Sanders et al., 1986).

Beneficial yield responses of peppers and other crops to plastic mulch culture have been primarily attributed to enhanced soil warming under the plastic (Taber, 1983). Maximum fruit production of bell peppers occurs with the root zone at $\approx 30 \mathrm{C}$ (Gosselin and Trudel, 1986). Black and clear plastic mulches are often used to warm root zones in the

Received for publication 3 July 1989. Technical contribution no. 2992 from the South Carolina Agricultural Experiment Station. This research was supported in part by S.C. Agricultural Experiment Station Project no. 1187 and a USDA Special Grant P.L. 89-106. We thank Heather Friend, Darre Daniels, Woodrow Sanders, and Terry Matheny for assistance and Mark Reddick of Reddick Fumigants for product support. Mention of a trade name does not constitute a guarantee or warranty of the product by the S.C. Agricultural Experiment Station or the USDA/ARS and does not imply approval to the exclusion of other products that may also be suitable. The cost of publishing this paper was defrayed in part by the payment of page charges. Under postal regulations, this paper therefore must be hereby marked advertisement solely to indicate this fact. grown bell pepper plants.

yPPFD of direct sunlight was $1673 \mu \mathrm{mol} \cdot \mathrm{s}^{-1} \cdot \mathrm{m}^{-2}$. have a phytoregulatory role in growth of young tomato (Lycopersicon esculentum Mill.) plants (Decoteau et al., 1988).

Limited research has been concerned with the effects of mulch color on reflected light and subsequent effects on pepper plant development, even though several colors of mulch are used. Porter and Etzel (1982) reported increased bell pepper yields with an aluminum-painted mulch, and they suggested that the increase was due to an increased amount of reflected photosynthetically active light.

The objectives of this research were to: 1) document the effects of mulch surface color on the development of field-grown bell peppers; 2) measure mulch color effects on the plant light environment and on root-zone temperatures in the field; 3 ) determine if bell peppers respond similarly to mulch color when root-zone temperatures are not influenced by mulch surface color; and 4) determine the sensitivity of peppers to subtle changes in the plant light environment.

The pepper cultivar Keystone Resistant Giant No. 3 was used in these experiments. Field plots for evaluation of mulch surface color effects on pepper growth, the plant light environment, and root-zone temperatures were located at the USDA/ARS Coastal Plains Soil and Water Conservation Research Center near Florence, S.C. The soil was a Norfolk loamy sand (Typic Paleudults). Lime was applied before land preparation at rates based on soil test results (target $\mathrm{pH}$ of 6.5). Fertilizer was applied at N, P, and $\mathrm{K}$ rates of 112, 160, and $310 \mathrm{~kg} \cdot \mathrm{ha}^{-1}$, respectively, and disked into the top $0.2 \mathrm{~m}$ of soil before bedding and mulch application. Black polyethylene (1.2 $\mathrm{m}$ wide $\times 0.03 \mathrm{~mm}$ thick), trickle irrigation tubing, and methyl bromide fumigant (at a rate of $280 \mathrm{~kg} \cdot \mathrm{ha}^{-1}$ ) were applied with a commercial mulch layer. The polyethylene mulch beds were $0.8 \mathrm{~m}$ wide $\times 0.1 \mathrm{~m}$ high.

Mulches of various colors were established by application of exterior enamel paint to the black plastic surface as described by Decoteau et al. (1989). Mulch treatments were arranged in a randomized complete-block design with four replicates per mulch treatment. Colored mulch plots were $6.1 \mathrm{~m}$ long with rows $1.8 \mathrm{~m}$ apart.

Plants were started in a greenhouse in plastic seedling trays $(5 \times 5$-cm cell size $)$

Table 1. Light reflection to a point $10 \mathrm{~cm}$ above colored mulch surfaces, and effects on size of ficld-

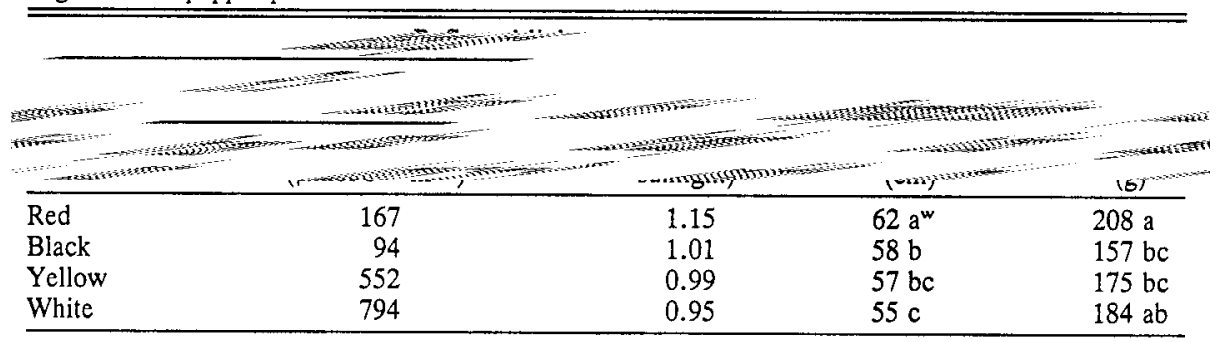

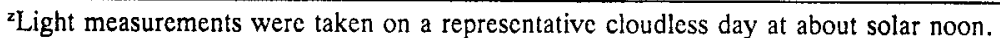

${ }^{x}$ The far-sed : red ratio of direct sunlight was assigned a value of 1.00 .

wMean separation in columns by Duncan's multiple range test, $P=0.05$. 


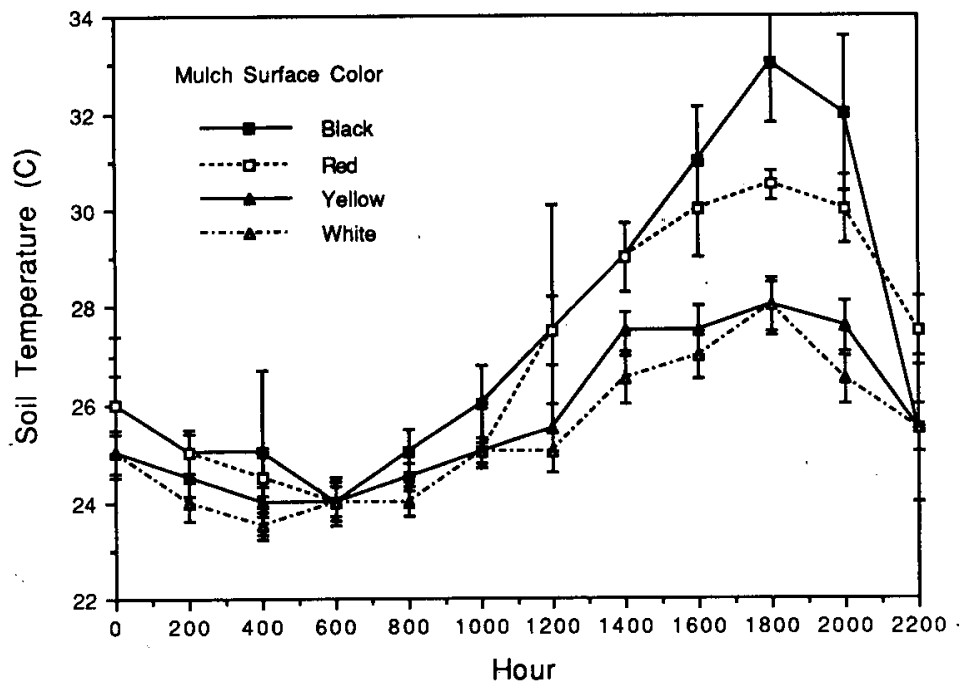

Fig. 1. Mulch surface color effects on soil temperatures $10 \mathrm{~cm}$ below the soil surface in bell pepper plots. Values are hourly averages from 3 to 17 June. Vertical lines represent SE of the means.

Table 2. Bell pepper plant development over mulches of diverse colors when root-zone tem. perature differences were minimized by use of insulation boards between the mulch and the soil.

\begin{tabular}{lccc}
\hline \hline & \multicolumn{3}{c}{ Plant size } \\
\cline { 2 - 4 } $\begin{array}{l}\text { Mulch } \\
\text { surface } \\
\text { color }\end{array}$ & $\begin{array}{c}\text { Height } \\
(\mathrm{cm})\end{array}$ & $\begin{array}{c}\text { Leaf area } \\
\left(\mathrm{cm}^{2}\right)\end{array}$ & $\begin{array}{c}\text { Shoot } \\
\text { dry mass } \\
(\mathrm{g})\end{array}$ \\
\hline Red & $42 \mathrm{a}^{2}$ & $3232 \mathrm{a}$ & $22 \mathrm{a}$ \\
Black & $39 \mathrm{a}$ & $2935 \mathrm{a}$ & $19 \mathrm{bc}$ \\
Silver & $33 \mathrm{~b}$ & $2893 \mathrm{a}$ & $18 \mathrm{c}$ \\
White & $35 \mathrm{~b}$ & $2812 \mathrm{a}$ & $21 \mathrm{ab}$ \\
\hline
\end{tabular}

${ }^{2}$ Mean separation in columns by Duncan's multiple range test, $P=0.05$.

Table 3. The effect of end-of-day red $(R)$ and far-red (FR) light applied for $15 \mathrm{~min}$ on bell pepper plant development.

\begin{tabular}{|c|c|c|c|c|}
\hline \multirow[b]{2}{*}{ Light } & \multirow[b]{2}{*}{ FR : R } & \multicolumn{3}{|c|}{ Plant size } \\
\hline & & $\begin{array}{l}\text { Height } \\
(\mathrm{cm})\end{array}$ & $\begin{array}{c}\text { Leaf area } \\
\left(\mathrm{cm}^{2}\right)\end{array}$ & $\begin{array}{c}\text { Shoot } \\
\text { dry mass } \\
\text { (g) }\end{array}$ \\
\hline FR & High & 10.4 & 306 & 1.4 \\
\hline & Low & 6.9 & 312 & 1.2 \\
\hline \multicolumn{2}{|c|}{ Significance $^{z}$} & $* *$ & NS & $*$ \\
\hline
\end{tabular}

${ }^{2}$ Statistical significance as indicated by Student's $t$-test.

Ns,*,**Nonsignificant or significant at $P=0.05$ or 0.01 , respectively.

containing a commercial potting mix. Sevenweek-old plants were transplanted into the mulch treatments on 29 Apr. 1986 at an inrow plant spacing of $0.45 \mathrm{~m}$, one row per bed. Recommended cultural practices for peppers (Cook et al., 1982) were followed throughout the study. Plant growth characteristics were determined 65 days after transplanting to the field. Plant heights were measured from the soil surface to the apical bud. The plants were then cut at the soil surface and dry weights of the top growth determined after oven-drying at $60 \mathrm{C}$.

Reflected light from each color of mulch was determined using a LI-COR 1800 Spectroradiometer with a remote light collector on a $1.5-\mathrm{m}$ fiber optic probe (LI-COR, Lincoln, Neb.) (Decoteau et al., 1988). Upwardly reflected light was measured $10 \mathrm{~cm}$ above the mulch surface on a representative clear day at about solar noon on plots that were not planted. The reflected light was expressed as a percentage of direct sunlight at each measured wavelength to determine shifts in spectral balance due to mulch color. Spectral irradiances at 735 and $645 \mathrm{~nm}$ were used to calculate the FR : $\mathrm{R}$ light ratios. These values were used because they approach the peaks for phytochrome action spectra in green plants (Kasperbauer et al., 1964). Temperatures were measured $10 \mathrm{~cm}$ below the soil surface in all plots from 5 to 17 June with a Campbell CR7 Datalogger equipped with copper-constantan fixed thermocouples (Omega Engineering, Stamford, Corm.).

The effect of mulch color on the development of pepper plants when root zone temperatures were excluded as a variable was determined using plant beds located in a glass greenhouse $(\max .=35 \mathrm{C}, \min .=20 \mathrm{C})$ at Clemson Univ.'s Pee Dee Research and Education Center in Florence, S.C. Seven-weekold pepper transplants, grown as described for the field experiment, were placed in plant beds $(3.4 \mathrm{~m}$ long $\times 1.0 \mathrm{~m}$ wide $\times 0.25 \mathrm{~m}$ deep) filled with a sterilized field soil (Norfolk loamy sand) on 11 Nov. 1986 at an inrow spacing of $0.3 \mathrm{~m}$. The soil in the plant beds was fertilized at $\mathrm{N}, \mathrm{P}$, and $\mathrm{K}$ rates of 67,168 , and $280 \mathrm{~kg} \cdot \mathrm{ha}^{-1}$, respectively. After allowing 5 days for the peppers to acclimate in the plant beds, styrofoam insulation boards ( $2.5 \mathrm{~cm}$ thick) were placed over the soil surface to minimize mulch surface color effects on soil temperatures. Black plastic was placed on the insulation boards and desired mulch colors painted on the upper surface of the plastic as previously described. Treatments were arranged in a randomized complete-block design with four replications of four plants per replication. Soil temperatures, measured $5 \mathrm{~cm}$ below the soil surface with the Campbell CR7 unit, did not significantly differ among mulch color treatments (data not pre- sented). Plants were sampled 65 days after application of insulation boards and initiation of mulch color treatments. Plant heights and dry weights were measured as previously described. Leaf areas were measured with a LI-COR 3100 area meter.

To illustrate how subtle changes in the plant light environment can influence pepper plant growth and development, young plants were grown in a controlled environment and exposed to 15 min of end-of-the-day R or FR light. These light treatments converted phytochrome into the far-red or red-absorbing form, respectively, at the end of the daily photosynthetic period. In this manner, all plants received the same light spectra and amount of photosynthetically active radiation during the day, but were influenced by phytochrome regulation of photosynthate partitioning, as described by Kasperbauer (1987). Pepper plants in this study were grown from seeds sown into 1-liter pots filled with a soilless mix (Terralite) and placed in a controlled environment room $(10 \mathrm{~m}$ long $\times 15$ $m$ wide) for germination and seedling growth. The controlled environment room was equipped with multi-vapor HID lights (General Electric Corp. ) that provided 315 $\mu \mathrm{mol} \cdot \mathrm{s}^{-1} \cdot \mathrm{m}^{-2}$ of photosynthetically active radiation during a 12-hr photoperiod. Average day and night temperatures were 27 and $21 \mathrm{C}$, respectively. Twenty-one days after emergence, end-of-day light treatments were initiated. At the end of each daily photosynthetic period, plants were placed in either a $\mathrm{R}$ or FR light exposure chamber for $15 \mathrm{~min}$ of treatment and then returned in darkness to the plant growing area of the controlled environment room. End-of-day R light treatment $\left(2.8\right.$ W. $\mathrm{m}^{-2}$ in the $600-$ to $700-\mathrm{nm}$ waveband) was obtained by filtering light from six cool-white, 40-W fluorescent lamps through a Roscolux \#19 acetate filter (Rosco, Port Chester, N.Y.). End-of-day FR light treatment $\left(10.2\right.$ W.m ${ }^{-2}$ in the 700 - to 780 $\mathrm{nm}$ waveband) was obtained by filtering radiation from two 150-W internal-reflector, incandescent-filament lamps through a polyacrylic sheet of cast acrylic \#2711, dark red (Rohm and Haas, Bristol, Pa.). There were four plants per light treatment. After 14 days of end-of-day light treatments, plants were harvested for growth and biomass determinations as previously described.

Mulch surface color influenced reflected light and root zone soil temperatures in the field experiment. The lighter (white and yellow) mulches reflected more photosynthetic light and smaller FR : $\mathrm{R}$ ratios than the darker (black and red) mulches (Table 1). The differences reported in reflected light among the mulch color treatments from the present study were similar to those reported to affect growth of tomato in a controlled environment (Decoteau et al., 1988). The light reflection from control (non-planted) plots was probably comparable to light reflection perceived by the peppers in the mulch plots during early vegetative growth. As the pepper plants grow and shade the mulch, the amount of reflected light from the mulch surfaces is probably reduced, but the growth-regulating 
effects of light or other microclimate variables already may have been perceived by the plant during its early growth stage. The plant light environment during early vegetative growth stage of tomato has been shown to affect subsequent flowering of tomato (Calvert, 1959).

In general, root-zone temperatures recorded in the afternoon and evening hours were cooler under the lighter-colored mulches than under the darker ones (Fig. 1). Rootzone soil temperatures at $1800 \mathrm{HR}$ averaged $33,30.5,28$, and 28C for black, red, yellow, and white mulches, respectively.

Mulch surface color affected the growth and development of bell pepper plants grown in the field (Table 1). Plants grown with red mulch were' taller than plants grown over black, yellow, or white mulch. Plants grown with red mulch were heavier than plants grown with black or yellow mulch. These results are similar to those reported for tomato plants that were grown with similar colored mulches (Decoteau et al., 1986).

When soil temperature differences among mulch color treatments were minimized by placing insulation boards between the plastic and the soil, growth of peppers was still affected by the mulch surface color (Table 2). Sixty-five days after initiation of mulch treatments, plants grown with the lightercolored mulches were shorter than plants in the darker ones. Plants from the red mulch treatment had more shoot biomass than plants grown with silver-colored or black mulch. Mulch color did not affect leaf area per plant. Hunt et al. (1989) reported similar plant growth responses to surface-reflected light for soybeans [Glycine max (L.) Merrill] that were grown over variously colored soil surfaces. These authors suggested that the amount of blue light as well as the FR : $\mathrm{R}$ ratio in reflected light contributed to the observed morphogenic effects.

Pepper plants treated with daily exposures of 15 min of FR light at end of day were taller and heavier than plants treated with 15 min of R light at end of day (Table 3). Increases in plant height induced by FR light treatment were due to longer internodes and not more nodes (data not presented). Increases in shoot biomass in the FR-treated plants appeared to be primarily due to increases in the growth of stems and petioles and not due to increases in leaf tissue, since there was no effect of end-of-day light treatment on plant leaf area or the number of leaves (data not presented).

Plastic mulch surface color affected the plant microclimate sufficiently to alter the growth of pepper plants in these studies. In the field, we measured differences in soil temperature and surface-reflected light among the mulch color treatments. Plant growth modifications in response to mulch color were also observed when soil temperatures among the treatments were not allowed to vary, providing evidence that mulch color-induced plant growth modifications could be influenced by a microclimate variable other than soil temperature. Pepper plants treated with end-of-day FR light had growth trends similar to plants grown over mulch colors that reflected relatively high FR : $\mathrm{R}$ ratios, and plants treated with end-of-day $\mathrm{R}$ light had growth trends similar to plants grown with mulch colors that reflected relatively low FR: $\mathrm{R}$ ratios. The similar response of pepper plant growth to differences in FR : $\mathrm{R}$ associated with end-of-day light treatments and to mulch color suggests that peppers respond to changes in the light microenvironment induced by light reflected from the variously colored plastic mulch surfaces.

\section{Literature Cited}

Brown, J.E., C.A. Lewis, J.T. Eason, M.E. Ruf, D.W. Porch, and M.E. Marvel. 1986. Effect of black plastic mulch and drip irrigation on bell pepper performance. Proc. Natl. Agr. Plastics Congr. 19:256-262.

Calvert, A. 1959. Effect of the early environment on the development of flowering in tomato: II. Light and temperature interactions. J. Hort. Sci. 34:154-162.

Cook, W.P., R.P. Griffin, and C.E. Drye. 1982. Commercial pepper and eggplant production. Clemson Univ. Coop. Ext. Serv. Hort. Lflt. 35.

Decoteau, D.R., D.D. Daniels, M.J. Kasperbauer, and P.G. Hunt. 1986. Colored plastic mulches and tomato morphogenesis. Proc. Natl.
Agr. Plastics Congr. 19:240-248.

Decoteau, D.R., M.J. Kasperbauer, D.D. Daniels, and P.G. Hunt. 1988. Plastic mulch color effects on reflected light and tomato plant growth Scientia Hort. 34:169-175.

Decoteau, D.R., M.J. Kasperbauer, and P.G. Hunt 1989. Mulch surface color affects yield of freshmarket tomatoes. J. Amer. Soc. Hort. Sci. 114:216-220.

Gosselin, A. and M.J. Trudel. 1986. Root-zone temperature effects on pepper. J. Amer. Soc. Hort. Sci. 111:220-224.

Hunt, P.G., M.J. Kasperbauer, and T.A. Matheny. 1989. Soybean seedling growth responses to light reflected from different colored soil surfaces. Crop Sci. 29: 130-133.

Kasperbauer, M.J. 1987. Far-red light reflection from green leaves and effects of phytochromemediated partitioning under field conditions. Plant Physiol. 85:350-354.

Kasperbauer, M.J., H.A. Borthwick, and S.B. Hendricks. 1964. Reversion of phytochrome 730 (Pfr) to P660 (Pr) in Chenopodium rubrum $\mathrm{L}$. Bot. Gaz. 125:75-80.

Kovalchuk, S. 1983. Record pepper yields -Plastic mulch, fumigation, and trickle irrigation. Amer. Veg. Grower 31:44, 46-47.

Locascio, S.J., J.G.A. Fiskel, D.A. Graetz, and R.D. Hauck. 1985. Nitrogen accumulation by pepper as influenced by mulch and time of fertilizer application. J. Amer. Soc. Hort. Sci. 110:325-328.

Monette, S. and K.A. Stewart. 1987. The effect of a windbreak and mulch on the growth and yield of pepper (Capsicum annuum L.) Can. J. Plant Sci. 67:315-320.

Porter, W.C. and W.W. EtzeL 1982. Effects of aluminum-painted mulch and black polyethylene mulches on bell pepper, Capsicum annuum L. HortScience 17:942-943.

Sanders, D.C., T.R. Konsler, W.J. Lament, and E.A. Estes. 1986. Pepper and muskmelon economics when grown with plastic mulch and trickle irrigation. Proc. Natl. Agr. Plastics Congr. 19:302-314.

Schalk, J.M., C.S. Creighton, R. Fery, W.R. Sitterly, B.W. Davis, T.L. McFadden, and A. Day. 1979. Reflective film mulches influence insect control and yield in vegetables. J. Amer. Soc. Hort. Sci. 104:759-762.

Taber, H.G. 1983. Effects of plastic soil and plant covers on Iowa tomato and muskmelon production. Proc. Natl. Agr. Plastics Congr. 17:3745 . 